\title{
Molecular identification and targeting of colorectal cancer stem cells
}

\author{
Kristel Kemper, Catarina Grandela and Jan Paul Medema \\ * LEXOR (Lab for Experimental Oncology and Radiobiology), Center for Experimental Molecular Medicine, Academic Medical \\ Center, Amsterdam, the Netherlands \\ Correspondence to: Kristel Kemper, e-mail: k.kemper@amc.uva.nl
}

Catarina Grandela, e-mail: a.c.martinsgrandela@amc.uva.nl

Jan Paul Medema, e-mail: j.p.medema@amc.uva.nl

Keywords: colon cancer stem cells, markers, targeting

Received: September 20, 2010, Accepted: October 8, 2010,

Published: October 9, 2010

Copyright: (C) Kemper et al. This is an open-access article distributed under the terms of the Creative Commons Attribution License, which permits unrestricted use, distribution, and reproduction in any medium, provided the original author and source are credited.

ABSTRACT:

Tumor initiating or cancer stem cells (CSCs) are suggested to be responsible for
tumor initiation and growth. Moreover, therapy resistance and minimal residual
disease are thought to result from selective resistance of CSCs. Isolation of CSCs
from colon carcinomas can be accomplished by selection of a subpopulation
of tumor cells based on expression of one or multiple cell surface markers
associated with cancer stemness, like CD133, CD44, CD24, CD29, CD166 and
Lgr5. Identification of colon CSCs will lead to a better rational for new therapies
that aim to target this fraction specifically. In this review, we analyze known
markers used for selection of colon CSCs and their potential function in CSC
biology. Moreover, we discuss potential targeting strategies for eradicating CSCs
specifically in order to develop more effective therapeutic strategies as well as to
address more fundamental questions like the actual role of CSCs in tumor growth.

\section{INTRODUCTION}

Tumors have long been viewed as a population in which all cells have the equal propensity to form new tumors, the so called conventional stochastic model. New insight was obtained when a small subset was discovered in acute myeloid leukemia (AML) $[1,2]$ that retained the ability to serially transplant. Since then, a new hierarchical model was born, claiming that tumors consist of a small fraction of so called tumor initiating cells, also referred to as cancer stem cells (CSCs) that are capable of initiating and maintaining tumor growth and a large fraction of more differentiated cells, which are incapable of maintaining tumor growth. After discovering these CSCs in hematological malignancies, their presence was also found in several solid tumors, like breast [3-5], lung [6], ovarian [7], liver [8], prostate [9], pancreas [10], skin [11], brain [12,13] and colon cancer [14-17], which will be the focus of this review. To prove the presence of CSCs within a tumor, several main criteria have been established by the scientific community: firstly, CSCs, identified by a specific cell surface marker, should be able to serially transplant the tumor in vivo; secondly, the tumors that grow out from the CSCs should resemble the original malignancy; thirdly, CSCs should be able to differentiate in marker-negative cells. To determine the CSC-frequency, in vivo limiting dilution assays (LDA) are performed, which means that several dilutions and multiple replicates of marker-positive or markernegative cancer cells are injected subcutaneously in (immunodeficient) mice. Cell surface markers that have been used for identification of colon CSCs are CD44 [1820], CD133 [14-17], CD166 [20], whereas expression of CD24 [17], CD29 [17] and Lgr5 [21] has also been found in colon CSCs. More functional markers like Wnt activity [22] and ALDH1 activity [23] have been exploited as well. Through identification of CSCs in colon cancer, more can be learned about the role of these cells in initiating and driving tumor growth. In this review, we examine the markers used for colon CSC identification and their possible function, as well as methods to target these CSCs specifically, both at therapeutic as wells as at a more fundamental level. 


\section{MARKERS USED TO IDENTIFY COLON CSC}

The five-transmembrane glycoprotein CD133 is one of the first colon CSCs markers identified and its use as a CSC marker has been controversial since then. Selecting colon cancer cells based on positivity for AC133, an epitope on the CD133 protein, identifies the tumorigenic and clonogenic population [14-17,24]. On the other hand, CD133 expression was found throughout the normal gastro-intestinal tract and therefore does not seem to be restricted to the stem cell compartment $[25,26]$. In addition, $\mathrm{CD}_{133^{+}}$as well as CD133- metastatic colon cancer cells were shown to be able to form new tumors, indicating that usage of CD133 as a CSC marker is questionable [26]. In this light, it is important to note two things. First, CD133 expression can be regulated by hypermethylating the $\mathrm{CpG}$ island in the CD133 promoter region, an event that frequently occurs in higher grade tumors and results in CD133 downregulation independent from its potential role in CSCs [27]. Secondly, the CD133 mRNA or surface expression is not changed during differentiation [24,28]. Instead the AC133 epitope is masked and inaccessible for the antibody in differentiated colon cancer cells, likely due to a difference in the glycosylation status and folding of the protein [24]. In agreement, the epitope can be reexposed by certain treatments, potentially explaining different outcomes in immunohistochemical stainings [24,26]. Although CD133 can be used as a CSC marker, it therefore should be done with caution.

The transmembrane glycoprotein CD44 has been used as a marker to isolate CSCs from multiple solid tumors, such as breast [3], head and neck [29], pancreas [30] and also colon cancer [31].Colon cancer cells sorted for $\mathrm{CD}_{4} 4^{+}$displayed high tumorigenicity, especially in combination with CD133-positivity, whereas CD44- cells could not form new tumors in immunodeficient mice $[19,20]$. CD44 can also be used in combination with mesenchymal stem cell marker CD166 (also referred to as ALCAM). $\mathrm{CD} 44^{+} \mathrm{CD} 166^{+}$colon cancer cells display a higher ability to form tumors in immunodeficient mice

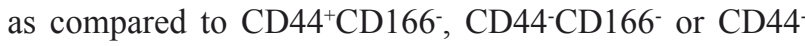
CD166- cell populations [20], making this an useful combination for the identification of colon CSCs.

In normal colon, integrin subunit $\beta 1$ (CD29) expression was observed in the lower parts of the crypt and thereby seems to mark a more stem/progenitor cell type [32]. Moreover, the combination of CD2 $4{ }^{\text {high }} \mathrm{CD} 29^{\text {high }}$ was suggested to identify the tumor initiation fraction in mouse colon carcinomas (R.Fodde, personal communication, [17]). Indeed, human colon CSCs were found to express high levels of CD24 and CD29 [17], suggesting that these markers can also identify human colon CSCs, although further evidence is necessary.

Not only cell surface markers, but also activity of certain pathways or enzymes can mark stemness. For instance, normal colon stem cells can be identified by the activity of aldehyde dehydrogenase 1 (ALDH1), a detoxifying enzyme that oxidizes intracellular aldehydes, therefore involved in the resistance to alkylating enzymes. ALDH1 activity can be measured by a method using dansyl aminoacetaldehyde and staining for ALDH1 revealed a few positive cells in the crypt [23]. In addition, when colon cancer cells were selected for ALDH1 activity using Aldeflour, $\mathrm{ALDH}^{+}$cells were able to initiate new tumors whereas $\mathrm{ALDH1}^{-}$cells were not [23], indicating that ALDH1 activity can be used as a colon CSC marker.

Besides the ALDH1 activity, recent evidence indicates that Wnt signaling activity can serve as a functional designation of colon CSCs [22]. Activating mutations in the Wnt pathway are pivotal in the initiation of the majority of colon cancers. However, recent evidence indicates that a clear heterogeneity in Wnt signaling still exists within separate cells within a colon cancer [33,34]. Interestingly, colon cancer cells with high Wnt activity express stem cell markers and have higher clonogenic capacity and tumorgenicity, whereas cells with low Wnt activity express higher levels of differentiation markers and are unable to give rise to new tumors [22]. In this light, it is interesting to note that Lgr5 is a Wnt target gene [35], exclusively expressed on the normal intestinal stem cells [36] and could thus also be a CSC marker. Interestingly, human colon CSCs were found to express Lgr5 [22]. In addition, tumorigenesis in mice is much more effective in $\mathrm{Lgr}^{+}$stem cells as compared to more differentiated cells [21]. However, formal evidence that Lgr5 identifies colon CSCs is still lacking and awaits the generation of reliable antibodies that can be used to isolate $\mathrm{Lgr}^{+}$tumor cells.

\section{FUNCTION OF CSC MARKERS AND THEIR RELEVANCE TO CSC BIOLOGY}

Most of the markers used for colon CSC isolation are chosen either because they are expressed in normal stem cells or were found to identify CSCs in other malignancies, either hematological or solid. The disadvantage of choosing markers in this fashion is that the functional effect of expression of the marker in CSCs is usually unknown. Also, the expression level (high versus low) used for identifying CSCs sometimes differs between tissue types [37]. Therefore, the choice of these markers is largely based on an "educated guess".

For instance, breast cancer cells expressing either no or low levels of single chain sialoglycoprotein CD24 in combination with CD44-positivity have been identified as CSCs [3], whereas in pancreas and colon, the CD24 high cells were shown to contain the tumor-initiating fraction $[10,17]$. CD24, first described as a cell surface marker for several haematopoietic cell populations, is known to play a role in cell-cell interaction [38,39], adhesion and proliferation $[40,41]$. Many cancers were found to over-express CD24 [42-44], indicating that the protein 
can play an important role in tumorigenesis. However, its role in CSC biology remains undefined, especially because the expression level by which the CSC should be selected differs between tissue types. Together with CD24, CD29-positivity has been used to identify the colon CSC population [17]. Cell surface receptor CD29, like CD24, mediates cell to extracellular matrix adhesion and can promote cancer progression by inducing invasion, migration and metastasis $[45,46]$. Its function in CSC biology has not been studied yet.

The choice for CD166 as a marker for CSCs was based on the heterogeneous expression of CD166 in colon carcinoma in combination with the finding that its expression correlates with a poor clinical outcome in colorectal cancer (CRC) patients [47]. Also CD166 is involved in regulation the formation of cell-cell contacts $[48,49]$. Even though the function of the debated CSC marker CD133 remains unknown, its presence in plasma membrane protrusions [50,51] as well as its ability to interact with plasma membrane cholesterol [52] suggests that the protein might play a role in establishing and maintaining plasmamembrane protrusions. This suggests that CD133 could play a role in cell polarity and migration [53] via cell-cell and cell-matrix interactions. In contrast, knockdown of CD133 in colon cancer cell lines or primary colon cultures did not influence the proliferation, migration, invasion, clonogenic and tumorigenic formation capacity $[19,54]$, indicating that the protein itself is not required for maintenance of the CSC state.

Interestingly, most of the CSC markers were chosen based on expression level instead of potential function in CSCs and most of them seem to play a role in inducing and/ or maintaining cell-cell or cell-matrix contact. A worrying aspect of such CSC markers is that enhanced attachment could in part explain why cells expressing these markers are more capable of growing in a new environment. Xenograft growth is currently the accepted/compulsory method to prove cancer stemness, but identification of adherence factors as CSC markers could simply be a reflection of the need for adherence in the assay itself. For this reason, it would be favorable to identify CSCs by markers that have a clear function in CSC biology.

CSC marker CD44 is one of those markers that might have a more functional role in CSC biology. For instance, knockdown of CD44 in primary colon cancer cell lines reduces clonogenicity in vitro and tumorgenicity in vivo [19]. CD44 is known to be involved in many cellular processes like survival, growth, differentiation and survival. As an important adhesion molecule, CD44 plays a major role in cancer cell migration. Several different splice variants are known for CD44. Interestingly, the ectodomain of one of its variants, CD44v6, was found to be required for c-Met activation in several tumors $[55,56]$. Moreover, hepatocyte growth factor (HGF), the ligand for c-Met, can restore the CSC phenotype in more differentiated colon cancer cells [22] and seems to play a major role in maintaining a CSC state. Therefore, CD44 itself may have a role in regulating stemness in CSCs and thus may be a functional cell surface CSC marker.

A more functional read-out of stemness in cancer cells is the activity of the ALDH1 enzyme. This enzyme, which oxidizes intracellular aldehydes, identifies the cells that are more resistant to alkylating agents [57-59]. Therefore, cells that have high ALDH1 activity are better protected against oxidative insults. In concordance, CSCs are thought to be more resistant to therapeutic agents [60-67]. In addition, ALDH1 convert retinol to retinoic acid. The effect of retinoids on cells is very dependent on the differentiation stage in which there are, but in hematopoietic stem cells (HSCs), retinoids have been shown to enhance self-renewal $[56,68]$. Therefore, high ALDH1 activity can have a dual role in maintaining a CSC state.

Another functional marker for CSCs, as recently identified by our group, is Wnt activity. For normal intestinal stem cells, Wnt activity is essential for maintaining stemness and crypt survival [69,70]. Important players in the Wnt signaling cascade, the tumor suppressor adenomatous polypolis coli (APC) and $\beta$-catenin, are frequently mutated in colon cancer. As a consequence, $\beta$-catenin will not be degraded by the APC complex and accumulation of $\beta$-catenin in the nucleus and consequent activation of Wnt target genes occurs [71]. However, despite the presence of these activating mutations, tumors display heterogeneous expression of nuclear $\beta$-catenin [33,34], indicating that alternative regulation of Wnt signaling is taking place. Cells with high Wnt activity represent the CSCs within the tumor. Importantly, extrinsic cues, like HGF produced by surrounding myofibroblasts in the stroma, were shown to modulate the Wnt signaling activity as well, providing a connection between the stroma and the CSCs [22].

As described above, some functional markers have been identified, but more will be needed. In addition, the currently used cell surface markers should be more investigated to discover their role in CSC biology.

\section{WHY TARGET CSC?}

Reliable markers that identify CSCs will pave the way to better understanding of signaling pathways and other regulatory mechanisms that determine stemness and differentiation of CSCs. As CSCs are considered to be the driving force behind tumor growth, therapies will have to focus on strategies that include targeting of CSCs. However, radio- or chemotherapy of cancer often incompletely eradicates tumor cells [60-67] and this is thought to be due to a selective survival advantage of CSCs, which could explain relapse of the tumor after many years. For example, studies have shown that colon CSCs are more resistant to treatment with 5-FU or oxaliplatin $[16,72]$. In addition, when CRC cell lines were 
treated with 5-FU or oxaliplatin in vitro, an increase in $\mathrm{CD} 133^{+} \mathrm{CD} 44^{+}$cells was observed [73], indicating that the CSC fraction was enriched and thus resistant to these therapeutics. Recurrence of colon cancer and appearance of distant metastasis many years after initial treatment are therefore hypothesized to be caused by residual CSCs. So, by targeting the CSCs specifically, it should be possible to obtain more complete degeneration of the tumor. Obviously, combination therapies that target both CSCs and more differentiated progeny will in the end be more efficient for use in the clinic. Especially as new studies have shown that factors produced by the microenvironment can revert differentiated cells back to a more stem cell-like state [22], indicating that killing the CSCs alone might not be sufficient to diminish tumor growth.

From a more scientific perspective, killing CSCs selectively in growing tumors could validate the currently favored hypothesis that CSCs are the only clonogenic cells within tumors. As indicated above, the current xenotransplantation assays define the cells that are capable of initiating tumor growth in immunocompromised mice. However, it is currently unclear whether these cells are also required to maintain growth of an existing tumor. Therefore, ablating CSCs selectively in growing tumors in vivo will give more insight into their biological role in tumors as well as their flexibility/plasticity.

\section{TARGETING CSC MARKERS}

A strategy to target CSCs is exploiting the presence of their cell surface markers. Membrane proteins can be targeted directly or used to internalize a death-inducing compound. For instance, in AML blasts, the first strategy was employed. One of the problems in AML is that blast cells are arrested in more progenitor-like state and do not fully differentiate. The CSC marker CD44 is known to play a role in normal myeloid differentiation, as this can be inhibited by CD44 blocking antibodies [74,75]. Treatment of AML blasts in vitro with CD44-activating monoclonal antibodies relieves the differentiation blockade. Moreover, in some cases, the CD44-activating antibodies could decrease proliferation and increase apoptosis of the blasts [76]. Additionally, leukemic stem cells (LSCs) could be killed in vivo when mice transplanted with AML cells were treated with the activating CD44 antibody H90. Ligation of CD44 inhibited the migration of LSCs to their niche, but also affected LSCs intrinsically, because repopulation capacity was severally affected afterwards $[16,77]$. Combined, this suggests that targeting CD44 could be a good strategy to attack CSCs.

The use of cell surface markers to guide toxic insults was employed by Wang et al. who targeted the CSC marker CD133 in glioblastoma (GBM). They conjugated an anti-CD133 antibody to single walled carbon nanotubes (SWNTs), which were developed to serve as an alternative option for localized hyperthermia treatment in comparison to gold-based nanomaterials [78,79]. Exposing CD133 GBM cells to these anti-CD133-SWNTs induced internalization of the SWNTs whereas CD133- cells did not take up the SWNTs. Exposing the cells to 808-nm near-infrared (NIR) laser light induced specific killing of the $\mathrm{CD} 133^{+}$cells. In vivo treatment of CD133+'-SWNTtreated GBM cells by NIR laser induced photothermolysis also significantly reduced tumor growth [80].

\section{TARGETING DIFFERENTIATION AND SURVIVAL SIGNALING IN CSC}

Since conventional therapies do not suffice in killing all tumor cells, the addition of a sensitizer targeting a pathway responsible for resistance of CSCs or inducing differentiation could overcome this problem. For instance, colon carcinomas are producing IL-4 that is responsible for upregulation anti-apoptotic molecules in these tumors. Inhibiting IL-4 by blocking antibodies sensitizes the cells for killing by 5-FU and oxaliplatin [16]. Also induction of differentiation in colon CSCs by exposing these cells to Bone Morphogenetic Protein 4 (BMP4), which can initiate a differentiation program as well as mediate apoptosis [81], sensitizes colon cancer cells to killing with 5 -FU or oxilaplatin in vivo, resulting in complete and long term regression of colon xenografts [82].

Also other signaling pathways were found to be involved in maintaining CSCs and therefore are thought to be essential for tumor growth. For instance, Hedgehog $(\mathrm{HH})$ signaling is suggested to play a role in CSCs of several tumor types, like glioblastoma [83], breast cancer [84], pancreatic cancer [85], multiple myeloma [86] and colon cancer [87]. To activate HH signaling, $\mathrm{HH}$ binds to the receptor Patched leading to the release of Patched-mediated repression of Smoothened (SMO) and to activation of the downstream Gli transcription factor family. In $\mathrm{CD}_{133^{+}}$advanced/metastatic colon cancer cells, higher levels of Gli1, a measure for $\mathrm{HH}$ activity, were found, compared to CD133- cells. Inhibition of $\mathrm{HH}$ signaling in primary colon cancer cell lines by knockdown of SMO reduces proliferation and induces apoptosis in vitro. In addition, in vivo tumor growth is abrogated by inhibition of $\mathrm{HH}$ signaling, because of reduced survival of CSCs [87].

Also Notch signaling has been identified as an essential pathway for the maintenance of the stem-cell like state of colon CSCs [88]. An important component of the Notch pathway is delta-like 4 ligand (DLL4). By inhibiting DLL4 with human monoclonal antibody $21 \mathrm{M} 18$ in colon carcinoma xenografts, the tumor growth as well as the CSC frequency, measured by the amount of $\mathrm{ESA}^{+} \mathrm{CD} 44^{+} \mathrm{CD} 166^{+}$cells is decreased compared to control. Interestingly, even though treatment of the xenografts with irinotecan, a chemotherapeutic often used in colon cancer, slowed down tumor growth, the frequency of $\mathrm{ESA}^{+} \mathrm{CD} 44^{+} \mathrm{CD} 166^{+}$cells and the clonogenicity was 
increased. Combination treatment of irinotecan with anti-hDLL4 reduced again the tumor growth and stem cell frequency, at even higher levels than the anti-DLL4 treatment alone [89]. This indicates that inhibiting Notch signaling reduces CSC frequencies and sensitizes tumor cells for irinotecan treatment.

\section{GENE SUICIDE THERAPY FOR TARGETING CSC AS PROOF OF PRINCIPLE}

As mentioned above, many studies support the existence of CSCs. However, sorting techniques to isolate $\mathrm{CSCs}$, as well as xenotransplantation assays needed to prove stemness, also disrupt the tumor microenvironment and likely introduce a selection bias. Therefore, it is difficult to prove that CSCs unequivocally exist. To study the actual role of CSCs in tumor growth in vivo, gene suicide therapy specifically against CSCs are needed. Using this strategy, suicide genes like the herpex simplex virys thymidine kinase (TK), diphtheria toxin or proapoptotic genes are placed under the regulation of a CSCspecific promoter. The activity of the suicide genes is then regulated either by a prodrug such as ganciclovir for TK or by combination with a genetic control mechanism, for instance using a stop cassette flanked by loxP sites so that suicide gene expression can be induced upon removal of the floxed cassette. CSCs can then be specifically targeted and the effect on tumor growth can be studied.

A method to target CSCs by a suicide gene that is independent of cell division is making use of Diphtheria Toxin A (DTA) gene. The DTA gene encodes for an adenosine diphosphate (ADP) ribosyltransferase which is responsible for ADP-ribosylation of elongation factor 2 . The effect of this ribosylation is that protein synthesis is inhibited and cell death is induced [90]. The advantage of this system is that only one molecule of DTA per cell is sufficient to induce cell death [91]. A recent study was published that made use of expressing DTA under a CSC marker. In this study, mouse glioma-initiating cells (GICs) were generated by overexpressing SV40 Large T antigen and oncogenic Ras in neural mouse stem cells. To be able to specifically eradicate GICs, these cells were genetically modified to carry the DTA gene by a floxed-lacZ cassette under the control of the CD133 locus as well as a CreER construct under the expression of a ubiquitous promoter. Injection of these GICs resulted in tumor formation that matched human glioma phenotypically. In addition, the tumors displayed a subset of cells that were CD133+. When the GICs were ablated from $\mathrm{CD}_{133^{+}}$cells by addition of tamoxifen in vitro and subsequently injected in vivo, the tumor formation was not affected, showing that $\mathrm{CD} 133^{+}$cells are not required for tumorigenesis in this model [92]. Whether this is also the case for colon cancer growth remains to be established. However, these findings could significantly change the CSC dogma and suggest that CSC-specific therapies may not be sufficient to treat cancer.

\section{CONCLUDING REMARKS}

Several markers have been used to identify colon CSCs, such as CD24, CD29, CD133, CD166, but the function of these proteins in CSC biology has not yet been clarified. Interestingly, these CSCs markers are involved in cellular adherence and since the golden standard in this field to identify CSCs by their capacity to recapitulate the original tumor when xenotransplanted into immunocompromised mice, the presence of adherence markers can be exploited by these cells to form new tumors. Therefore, the role of CSCs markers in maintaining a stem cell state should be investigated and more functionally important markers should be identified, like CD44, ALDH1 activity and Wnt signaling. Combination of previously known and new markers could lead to more directed therapy that specifically targets CSCs. At therapeutic and scientific level, specific targeting of CSCs could give more insight into how and whether these CSCs maintain tumor growth and in which way we can eradicate them. Studies that target CSCs within a growing tumor by suicide gene therapy could give not only more insight into their ability to maintain tumor growth, but also into their flexibility/plasticity within a tumor. This is especially relevant as an increasing number of studies indicate a role for the microenvironment/niche in the maintenance CSCs, which could even be dominant. Although this role is currently ill-defined it could provide novel clues for CSC biology as well as therapy.

\section{REFERENCES}

1. Bonnet D and Dick JE. Human acute myeloid leukemia is organized as a hierarchy that originates from a primitive hematopoietic cell. Nature Medicine 1997; 3: 730-737

2. Lapidot T, Sirard C, Vormoor J, Murdoch B, Hoang T, Cacerescortes J, Minden M, Paterson B, Caligiuri MA, and Dick JE. A Cell Initiating Human Acute Myeloid-Leukemia After Transplantation Into Scid Mice. Nature 1994; 367: 645-648

3. Al Hajj M, Wicha MS, Benito-Hernandez A, Morrison SJ, and Clarke MF. Prospective identification of tumorigenic breast cancer cells. Proceedings of the National Academy of Sciences of the United States of America 2003; 100: 3983-3988

4. Clarke M, Al Hajj M, Wicha M, Nunez G, and Morrison $\mathrm{S}$. Prospective identification and isolation of breast cancer tumor initiating cells. European Journal of Cancer 2002; 38: S104-S104

5. Ponti D, Costa A, Zaffaroni N, Pratesi G, Petrangolini G, Coradini D, Pilotti S, Pierotti MA, and Daidone MG. Isolation and in vitro propagation of tumorigenic breast 
cancer cells with stem/progenitor cell properties. Cancer Research 2005; 65: 5506-5511

6. Eramo A, Lotti F, Sette G, Pilozzi E, Biffoni M, Di Virgilio A, Conticello C, Ruco L, Peschle C, and De Maria R. Identification and expansion of the tumorigenic lung cancer stem cell population. Cell Death and Differentiation 2008; 15: $504-514$

7. Curley MD, Therrien VA, Cummings CL, Sergent PA, Koulouris CR, Friel AM, Roberts DJ, Seiden MV, Scadden DT, Rueda BR, and Foster R. CD133 Expression Defines a Tumor Initiating Cell Population in Primary Human Ovarian Cancer. Stem Cells 2009; 27: 2875-2883

8. Yang ZF, Ho DW, Ng MN, Lau CK, Yu WC, Ngai P, Chu PWK, Lam CT, Poon RTP, and Fan ST. Significance of $\mathrm{CD} 90(+)$ cancer stem cells in human liver cancer. Cancer Cell 2008; 13: 153-166

9. Collins AT, Berry PA, Hyde C, Stower MJ, and Maitland NJ. Prospective identification of tumorigenic prostate cancer stem cells. Cancer Research 2005; 65: 10946-10951

10. Li CW, Heidt DG, Dalerba P, Burant CF, Zhang LJ, Adsay V, Wicha M, Clarke MF, and Simeone DM. Identification of pancreatic cancer stem cells. Cancer Research 2007; 67: 1030-1037

11. Monzani E, Facchetti F, Galmozzi E, Corsini E, Benetti A, Cavazzin C, Gritti A, Piccinini A, Porro D, Santinami M, Invernici G, Parati E, Alessandri G, and La Porta CAM. Melanoma contains CD133 and ABCG2 positive cells with enhanced tumourigenic potential. European Journal of Cancer 2007; 43: 935-946

12. Singh SK, Clarke ID, Terasaki M, Bonn VE, Hawkins C, Squire J, and Dirks PB. Identification of a cancer stem cell in human brain tumors. Cancer Research 2003; 63: 58215828

13. Singh SK, Hawkins C, Clarke ID, Squire J, Bayani J, Hide T, Cusimano MD, and Dirks PB. Adult human glioma growth is exclusively maintained in vitro and in vivo by CD133+cancer stem cells. Neuro-Oncology 2004; 6: 348348

14. O'Brien CA, Pollett A, Gallinger S, and Dick JE. A human colon cancer cell capable of initiating tumour growth in immunodeficient mice. Nature 2007; 445: 106-110

15. Ricci-Vitiani L, Lombardi DG, Pilozzi E, Biffoni M, Todaro M, Peschle C, and De Maria R. Identification and expansion of human colon-cancer-initiating cells. Nature 2007; 445: 111-115

16. Todaro M, Alea MP, Di Stefano AB, Cammareri P, Vermeulen L, Iovino F, Tripodo C, Russo A, Gulotta G, Medema JP, and Stassi G. Colon cancer stem cells dictate tumor growth and resist cell death by production of interleukin-4. Cell Stem Cell 2007; 1: 389-402

17. Vermeulen L, Todaro M, de Sousa MF, Sprick MR, Kemper K, Perez AM, Richel DJ, Stassi G, and Medema JP. Single-cell cloning of colon cancer stem cells reveals a multi-lineage differentiation capacity. Proc.Natl.Acad.
Sci.U.S.A 2008; 105: 13427-13432

18. Chu P, Clanton DJ, Snipas TS, Lee J, Mitchell E, Nguyen ML, Hare E, and Peach RJ. Characterization of a subpopulation of colon cancer cells with stem cell-like properties. International Journal of Cancer 2009; 124: 1312-1321

19. Du L, Wang HY, He LY, Zhang JY, Ni BY, Wang XH, Jin HJ, Cahuzac N, Mehrpour M, Lu YY, and Chen Q. CD44 is of Functional Importance for Colorectal Cancer Stem Cells. Clinical Cancer Research 2008; 14: 6751-6760

20. Dalerba P, Dylla SJ, Park IK, Liu R, Wang XH, Cho RW, Hoey T, Gurney A, Huang EH, Simeone DM, Shelton AA, Parmiani G, Castelli C, and Clarke MF. Phenotypic characterization of human colorectal cancer stem cells. Proceedings of the National Academy of Sciences of the United States of America 2007; 104: 10158-10163

21. Barker N, Ridgway RA, van Es JH, van de Wetering M, Begthel H, van den Born M, Danenberg E, Clarke AR, Sansom OJ, and Clevers H. Crypt stem cells as the cells-oforigin of intestinal cancer. Nature 2009; 457: 608-U119

22. Vermeulen L, Melo FDSE, van der Heijden M, Cameron K, de Jong JH, Borovski T, Tuynman JB, Todaro M, Merz C, Rodermond H, Sprick MR, Kemper K, Richel DJ, Stassi G, and Medema JP. Wnt activity defines colon cancer stem cells and is regulated by the microenvironment. Nature Cell Biology 2010; 12: 468-U121

23. Huang EH, Hynes MJ, Zhang T, Ginestier C, Dontu G, Appelman H, Fields JZ, Wicha MS, and Boman BM. Aldehyde Dehydrogenase 1 Is a Marker for Normal and Malignant Human Colonic Stem Cells (SC) and Tracks SC Overpopulation during Colon Tumorigenesis. Cancer Research 2009; 69: 3382-3389

24. Kemper K, Sprick MR, de Bree M, Scopelliti A, Vermeulen L, Hoek M, Zeilstra J, Pals ST, Mehmet H, Stassi G, and Medema JP. The AC133 Epitope, but not the CD133 Protein, Is Lost upon Cancer Stem Cell Differentiation. Cancer Research 2010; 70: 719-729

25. Karbanova J, Missol-Kolka E, Fonseca AV, Lorra C, Janich P, Hollerova H, Jaszai J, Ehrmann J, Kolar Z, Liebers C, Arl S, Subrtova D, Freund D, Mokry J, Huttner WB, and Corbeil D. The Stem Cell Marker CD133 (Prominin-1) Is Expressed in Various Human Glandular Epithelia. Journal of Histochemistry \& Cytochemistry 2008; 56: 977-993

26. Shmelkov SV, Butler JM, Hooper AT, Hormigo A, Kushner J, Milde T, St Clair R, Baljevic M, White I, Jin DK, Chadburn A, Murphy AJ, Valenzuela DM, Gale NW, Thurston G, Yancopoulos GD, D’Angelica M, Kemeny N, Lyden D, and Rafii S. CD133 expression is not restricted to stem cells, and both CD133+ and CD133- metastatic colon cancer cells initiate tumors. J.Clin.Invest 2008; 118: 21112120

27. Jeon YK, Kim SH, Choi SH, Kim KH, Yoo BC, Ku JL, and Park JG. Promoter hypermethylation and loss of CD133 gene expression in colorectal cancers. World Journal of Gastroenterology 2010; 16: 3153-3160 
28. Taieb N, Maresca M, Guo XJ, Garmy N, Fantini J, and Yahi $\mathrm{N}$. The first extracellular domain of the tumour stem cell marker CD133 contains an antigenic ganglioside-binding motif. Cancer Lett. 2009; 278: 164-173

29. Prince ME, Sivanandan R, Kaczorowski A, Wolf GT, Kaplan MJ, Dalerba P, Weissman IL, Clarke MF, and Ailles LE. Identification of a subpopulation of cells with cancer stem cell properties in head and neck squamous cell carcinoma. Proceedings of the National Academy of Sciences of the United States of America 2007; 104: 973978

30. Li CW, Heidt DG, Dalerba P, Burant CF, Zhang LJ, Adsay V, Wicha M, Clarke MF, and Simeone DM. Identification of pancreatic cancer stem cells. Cancer Research 2007; 67: 1030-1037

31. Dalerba P, Dylla SJ, Park IK, Liu R, Wang XH, Cho RW, Hoey T, Gurney A, Huang EH, Simeone DM, Shelton AA, Parmiani G, Castelli C, and Clarke MF. Phenotypic characterization of human colorectal cancer stem cells. Proceedings of the National Academy of Sciences of the United States of America 2007; 104: 10158-10163

32. Fujimoto $\mathrm{K}$, Beauchamp RD, and Whitehead RH. Identification and isolation of candidate human colonic clonogenic cells based on cell surface integrin expression. Gastroenterology 2002; 123: 1941-1948

33. Brabletz T. Variable beta-catenin expression in colorectal cancers indicates tumor progression driven by the tumor environment. 2001;

34. Fodde R. Wnt/beta-catenin signaling in cancer stemness and malignant behavior. 2007;

35. Van Der Flier LG, Sabates-Bellver J, Oving I, Haegebarth A, De Palo M, Anti M, Van Gijn ME, Suijkerbuijk S, van de Wetering M, Marra G, and Clevers H. The intestinal Wnt/TCF signature. Gastroenterology 2007; 132: 628-632

36. Barker N, van Es JH, Kuipers J, Kujala P, van den Born M, Cozijnsen M, Haegebarth A, Korving J, Begthel H, Peters $\mathrm{PJ}$, and Clevers H. Identification of stem cells in small intestine and colon by marker gene Lgr5. Nature 2007; 449: 1003-10U1

37. Alison MR, Islam S, and Lim SML. Number crunching in the cancer stem cell market. Breast Cancer Research 2009; 11:

38. Aigner S, Sthoeger ZM, Fogel M, Weber E, Zarn J, Ruppert M, Zeller Y, Vestweber D, Stahel R, Sammar M, and Altevogt P. CD24, a mucin-type glycoprotein, is a ligand for P-selectin on human tumor cells. Blood 1997; 89: 33853395

39. Aigner S, Ramos CL, Hafezi-Moghadam A, Lawrence MB, Friederichs J, Altevogt P, and Ley K. CD24 mediates rolling of breast carcinoma cells on P-selectin. Faseb Journal 1998; 12: $1241-1251$

40. Chappel MS, Hough MR, Mittel A, Takei F, Kay R, and Humphries RK. Cross-linking the murine heatstable antigen induces apoptosis in B cell precursors and suppresses the anti-CD40-induced proliferation of mature resting B lymphocytes. Journal of Experimental Medicine 1996; 184: 1639-1649

41. Liu Y, Jones B, Brady W, Janeway CA, and Linley PS. CoStimulation of Murine Cd4 T-Cell Growth - Cooperation Between B7 and Heat-Stable Antigen. European Journal of Immunology 1992; 22: 2855-2859

42. Jacob J, Bellach J, Grutzmann R, Alldinger I, Pilarsky C, Dietel M, and Kristiansen G. Expression of CD24 in adenocarcinomas of the pancreas correlates with higher tumor grades. Pancreatology 2004; 4: 454-460

43. Kristiansen G, Pilarsky C, Pervan J, Sturzebecher B, Stephan C, Jung K, Loening S, Rosenthal A, and Dietell M. $\mathrm{CD} 24$ expression is a significant predictor of PSA relapse and poor prognosis in low grade or organ confined prostate cancer. Prostate 2004; 58: 183-192

44. Sorbello V, Fuso L, Sfiligoi C, Scafoglio C, Ponzone R, Biglia N, Weisz A, Sismondi P, and De Bortoli M. Quantitative real-time RT-PCR analysis of eight novel estrogen-regulated genes in breast cancer. International Journal of Biological Markers 2003; 18: 123-129

45. Elliott BE, Ekblom P, Pross H, Niemann A, and Rubin K. Anti-Beta(1)-Integrin Igg Inhibits Pulmonary Macrometastasis and the Size of Micrometastases from A Murine Mammary-Carcinoma. Cell Adhesion and Communication 1994; 1: 319-332

46. Fujita S, Watanabe M, Kubota T, Teramoto T, and Kitajima M. Alteration of Expression in Integrin Beta(1)-Subunit Correlates with Invasion and Metastasis in ColorectalCancer. Cancer Letters 1995; 91: 145-149

47. Weichert W, Knosel T, Bellach J, Dietel M, and Kristiansen G. ALCAM/CD166 is overexpressed in colorectal carcinoma and correlates with shortened patient survival. Journal of Clinical Pathology 2004; 57: 1160-1164

48. Tomita K, van Bokhoven A, Jansen CFJ, Bussemakers MJG, and Schalken JA. Coordinate recruitment of E-cadherin and ALCAM to cell-cell contacts by alpha-catenin. Biochemical and Biophysical Research Communications 2000; 267 : 870-874

49. Zimmerman AW, Nelissen JMDT, Emst-De Vries SE, Willems PHGM, de Lange F, Collard JG, van Leeuwen FN, and Figdor CG. Cytoskeletal restraints regulate homotypic ALCAM-mediated adhesion through PKC alpha independently of Rho-like GTPases. Journal of Cell Science 2004; 117: 2841-2852

50. Corbeil D, Roper K, Hellwig A, Tavian M, Miraglia S, Watt SM, Simmons PJ, Peault B, Buck DW, and Huttner WB. The human AC133 hematopoietic stem cell antigen is also expressed in epithelial cells and targeted to plasma membrane protrusions. Journal of Biological Chemistry 2000; 275: 5512-5520

51. Weigmann A, Corbeil D, Hellwig A, and Huttner WB. Prominin, a novel microvilli-specific polytopic membrane protein of the apical surface of epithelial cells, is targeted 
to plasmalemmal protrusions of non-epithelial cells. Proceedings of the National Academy of Sciences of the United States of America 1997; 94: 12425-12430

52. Roper K, Corbeil D, and Huttner WB. Retention of prominin in microvilli reveals distinct cholesterol-based lipid micro-domains in the apical plasma membrane. Nature Cell Biology 2000; 2: 582-592

53. Giebel B, Corbeil D, Beckmann J, Hohn J, Freund D, Giesen K, Fischer J, Kogler G, and Wernet P. Segregation of lipid raft markers including CD133 in polarized human hematopoietic stem and progenitor cells. Blood 2004; 104: 2332-2338

54. Horst D, Scheel SK, Liebmann S, Neumann J, Maatz S, Kirchner $\mathrm{T}$, and Jung A. The cancer stem cell marker CD133 has high prognostic impact but unknown functional relevance for the metastasis of human colon cancer. Journal of Pathology 2009; 219: 427-434

55. Orian-Rousseau V, Chen LF, Sleeman JP, Herrlich P, and Ponta H. CD44 is required for two consecutive steps in HGF/c-Met signaling. Genes \& Development 2002; 16: 3074-3086

56. Baba T, Convery PA, Matsumura N, Whitaker RS, Kondoh E, Perry T, Huang Z, Bentley RC, Mori S, Fujii S, Marks JR, Berchuck A, and Murphy SK. Epigenetic regulation of CD133 and tumorigenicity of CD133+ovarian cancer cells. Oncogene 2009; 28: 209-218

57. Gordon MY. 4-Hydroperoxycyclophosphamide Inhibits Proliferation by Human Granulocyte-Macrophage ColonyForming Cells (Gm-Cfc) But Spares More Primitive Progenitor Cells. 1985;

58. Sahovic EA. Role for Aldehyde Dehydrogenase in Survival of Progenitors for Murine Blast Cell Colonies After Treatment with 4-Hydroperoxycyclophosphamide Invitro. 1988 ;

59. Sladek NE. Cellular levels of aldehyde dehydrogenases (ALDH1A1 and ALDH3A1) as predictors of therapeutic responses to cyclophosphamide-based chemotherapy of breast cancer: a retrospective study - Rational individualization of oxazaphosphorine-based cancer chemotherapeutic regimens. 2002;

60. Baba T. Epigenetic regulation of CD133 and tumorigenicity of CD133+ovarian cancer cells. 2009;

61. Eramo A. Chemotherapy resistance of glioblastoma stem cells. 2006;

62. Eramo A. Identification and expansion of the tumorigenic lung cancer stem cell population. 2008;

63. Folkins C. Anticancer therapies combining antiangiogenic and tumor cell cytotoxic effects reduce the tumor stem-like cell fraction in glioma xenograft tumors. 2007;

64. Hermann PC. Distinct populations of cancer stem cells determine tumor growth and metastatic activity in human pancreatic cancer. 2007;

65. Li XX. Intrinsic resistance of tumorigenic breast cancer cells to chemotherapy. 2008;
66. Ma S. CD133(+) HCC cancer stem cells confer chemoresistance by preferential expression of the Akt/PKB survival pathway. 2008;

67. Yu JS. CD133 positive glioblastoma stem cells are resistant to chemotherapy and overexpress multiple drug resistance genes and anti-apoptosis genes. 2006;

68. Purton LE, Bernstein ID, and Collins SJ. All-trans retinoic acid enhances the long-term repopulating activity of cultured hematopoietic stem cells. Blood 2000; 95: 470477

69. Korinek V, Barker N, Moerer P, van Donselaar E, Huls G, Peters PJ, and Clevers H. Depletion of epithelial stem-cell compartments in the small intestine of mice lacking Tcf-4. Nature Genetics 1998; 19: 379-383

70. Hermann PC, Huber SL, Herrler T, Aicher A, Ellwart JW, Guba M, Bruns CJ, and Heeschen C. Distinct populations of cancer stem cells determine tumor growth and metastatic activity in human pancreatic cancer. Cell Stem Cell 2007; 1: 313-323

71. van de Wetering M, Sancho E, Verweij C, de Lau W, Oving I, Hurlstone A, van der Horn K, Batlle E, Coudreuse D, Haramis AP, Tion-Pon-Fong M, Moerer P, van den Born M, Soete G, Pals S, Eilers M, Medema R, and Clevers H. The beta-catenin/TCF-4 complex imposes a crypt progenitor phenotype on colorectal cancer cells. Cell 2002; 111: 241-250

72. Cammareri P, Scopelliti A, Todaro M, Eterno V, Francescangeli F, Moyer MP, Agrusa A, Dieli F, Zeuner A, and Stassi G. Aurora-A Is Essential for the Tumorigenic Capacity and Chemoresistance of Colorectal Cancer Stem Cells. Cancer Research 2010; 70: 4655-4665

73. Dallas NA, Xia L, Fan F, Gray MJ, Gaur P, Van Buren G, Samuel S, Kim MP, Lim SJ, and Ellis LM. Chemoresistant Colorectal Cancer Cells, the Cancer Stem Cell Phenotype, and Increased Sensitivity to Insulin-like Growth Factor-I Receptor Inhibition. Cancer Research 2009; 69: 1951-1957

74. Ghaffari S, Dougherty GJ, Lansdorp PM, Eaves AC, and Eaves CJ. Differentiation - Associated Changes in Cd44 Isoform Expression During Normal Hematopoiesis and Their Alteration in Chronic Myeloid-Leukemia. Blood 1995; 86: 2976-2985

75. Miyake K, Underhill CB, Lesley J, and Kincade PW. Hyaluronate Can Function As A Cell-Adhesion Molecule and Cd44 Participates in Hyaluronate Recognition. Journal of Experimental Medicine 1990; 172: 69-75

76. Charrad RS, Li Y, Delpech B, Balitrand N, Clay D, Jasmin C, Chomienne C, and Smadja-Joffe F. Ligation of the CD44 adhesion molecule reverses blockage of differentiation in human acute myeloid leukemia. Nature Medicine 1999; 5: 669-676

77. Jin LQ, Hope KJ, Zhai QL, Smadja-Joffe F, and Dick JE. Targeting of CD44 eradicates human acute myeloid leukemic stem cells. Nature Medicine 2006; 12: 1167-1174

78. Hirsch LR, Stafford RJ, Bankson JA, Sershen SR, Rivera 
B, Price RE, Hazle JD, Halas NJ, and West JL. Nanoshellmediated near-infrared thermal therapy of tumors under magnetic resonance guidance. Proceedings of the National Academy of Sciences of the United States of America 2003; 100: 13549-13554

79. Tong L, Zhao Y, Huff TB, Hansen MN, Wei A, and Cheng JX. Gold nanorods mediate tumor cell death by compromising membrane integrity. Advanced Materials 2007; 19: 3136-+

80. Wang $\mathrm{CH}$, Chiou SH, Chou CP, Chen YC, Huang YJ, and Peng CA. Photothermolysis of glioblastoma stem-like cell targeted by carbon nanotubes conjugated with CD133 monoclonal antibody. Nanomedicine 2010;

81. Nishanian TG, Kim JS, Foxworth A, and Waldman T. Suppression of tumorigenesis and activation of Wnt signaling by bone morphogenetic protein 4 in human cancer cells. Cancer Biology \& Therapy 2004; 3: 667-675

82. Todaro M, Francipane MG, Medema JP, and Stassi G. Colon Cancer Stem Cells: Promise of Targeted Therapy. Gastroenterology 2010; 138: 2151-2162

83. Clement V, Sanchez P, de Tribolet N, Radovanovic I, and Altaba ARI. HEDGEHOG-GLI1 signaling regulates human glioma growth, cancer stem cell self-renewal, and tumorigenicity. Current Biology 2007; 17: 165-172

84. Liu SL, Dontu G, Mantle ID, Patel S, Ahn NS, Jackson KW, Suri P, and Wicha MS. Hedgehog signaling and Bmi1 regulate self-renewal of normal and malignant human mammary stem cells. Cancer Research 2006; 66: 6063 6071

85. Feldmann G, Dhara S, Fendrich V, Bedja D, Beaty R, Mullendore M, Karikari C, Alvarez H, Iacobuzio-Donahue C, Jimeno A, Gabrielson KL, Matsui W, and Maitra A. Blockade of hedgehog signaling inhibits pancreatic cancer invasion and metastases: A new paradigm for combination therapy in solid cancers. Cancer Research 2007; 67: 2187 2196

86. Peacock CD, Wang QJ, Gesell GS, Corcoran-Schwartz IM, Jones E, Kim J, Devereux WL, Rhodes JT, Huff CA, Beachy PA, Watkins DN, and Matsui W. Hedgehog signaling maintains a tumor stem cell compartment in multiple myeloma. Proceedings of the National Academy of Sciences of the United States of America 2007; 104: 4048-4053

87. Varnat F, Duquet A, Malerba M, Zbinden M, Mas C, Gervaz P, and Altaba ARI. Human colon cancer epithelial cells harbour active HEDGEHOG-GLI signalling that is essential for tumour growth, recurrence, metastasis and stem cell survival and expansion. Embo Molecular Medicine 2009; 1: 338-351

88. Sikandar SS, Pate KT, Anderson S, Dizon D, Edwards RA, Waterman ML, and Lipkin SM. NOTCH Signaling Is Required for Formation and Self-Renewal of TumorInitiating Cells and for Repression of Secretory Cell Differentiation in Colon Cancer. Cancer Research 2010; 70: $1469-1478$
89. Hoey T, Yen WC, Axelrod F, Basi J, Donigian L, Dylla S, Fitch-Bruhns M, Lazetic S, Park IK, Sato A, Satyal S, Wang XH, Clarke MF, Lewicki J, and Gurney A. DLL4 Blockade Inhibits Tumor Growth and Reduces TumorInitiating Cell Frequency. Cell Stem Cell 2009; 5: 168-177

90. Pappenheimer AM. Diphtheria-Toxin. Annual Review of Biochemistry 1977; 46: 69-94

91. Yamaizumi M, Mekada E, Uchida T, and Okada Y. One Molecule of Diphtheria-Toxin Fragment A Introduced Into A Cell Can Kill Cell. Cell 1978; 15: 245-250

92. Nishide $\mathrm{K}$, Nakatani $\mathrm{Y}$, Kiyonari $\mathrm{H}$, and Kondo $\mathrm{T}$. Glioblastoma Formation from Cell Population Depleted of Prominin1-Expressing Cells. Plos One 2009; 4: 